\title{
Universal And Existential Perfects in BRAZILIAN PORTUGUESE
}

\section{Perfeitos universais e existenciais em português brasileiro}

\author{
Karina Molsing*
}

\section{INTRODUCTION}

The main readings of the Present Perfect in English (PrP) are summarized below in (1) (COMRIE, 1976, MCCAWLEY, 1971).

(1) a. John has lived in New York for 4 years. (UNIVERSAL)

b. John has visited Paris before.

(Experiential)

c. John has arrived.

(Resultative) (EXISTENTIAL)

d. John has just graduated from college.

(Recent past)

It has been noted by some (RATHERT, 2003; PANCHEVA, 2003; IATRIDOU et al., 2003) that there are some cases of the Present Perfect in which there is an ambiguity between the Universal and Existential Perfects (U-perfects vs. E-perfects, respectively). For example, (1a) could mean that John still lives in New York at speech time, or that there was some time in the past at which John lived in New York for four years. The nature of the distinction between these two readings and how we get them is one of the main foci of this paper. I will also discuss the role of adverbs in the two types of perfects. The second major question to be dealt with in this paper regards whether the traditionally recognized readings for the Present Perfect ${ }^{1}$ in Brazilian Portuguese, the Pretérito Perfeito Composto (PPC), illustrated in (2), correspond to the U and E-perfects in English. And if so, whether the PPC also presents the $\mathrm{U} / \mathrm{E}$ ambiguity.

\footnotetext{
Mestre e doutoranda em linguística aplicada pela PUCRS

I will use 'Present Perfect' with capital first letters to refer to the morphological structure across languages. I will use 'PrP' for the English Present Perfect meaning and 'PPC' for the Brazilian Portuguese Present Perfect meaning.
} 


\section{(ITERATIVE)}

(2) a. O Bruno tem ido a Disney. (várias vezes)

The Bruno has gone to Disneyland (various times)

'Bruno has been going to Disneyland (many times)'

(DURATIVE)

b. A Maria tem sido feliz na Europa.

The Maria has been happy in-the Europe

'Mary has been happy in Europe'

I defend in this paper that the PPC presents both $U$ and E-perfects as well as the U/E ambiguity, although it is slightly different from the ambiguity displayed in English. The difference comes from the inability of the PPC to express single, perfective eventualities. This means that (2a) must express many times and never one time. I extend this claim further in that the PPC cannot express any specific number of bounded events, with adverbs like 'three times', for example. So, the notion that an E-perfect is possible goes against claims that Portuguese only has a U-perfect (BRUGGER, 1978 SQUARTINI; BERTINETTO, 2000; PANCHEVA, 2003). Motivated by similar surface structure ('have' + past participle ; 'ter' + particípio passado) and some semantic overlap in meanings, revealed in examples like (2b), I defend that the meaning of the PPC is not semantically divergent from the Present Perfect of other more studied languages, and that language-specific differences can be derived from composition with other morphosyntactic elements. The present work also aims to contribute to the discussion of the role of adverbs in the Present Perfect and propose adjustments to account for a broader range of data. Hence, the objective of this paper is quite modest, given the complexity of the phenomena involved in composing the PPC, as I only propose to analyze the ambiguities of the readings involved in the PPC structure and not provide an account of the origins of the iterativity, as illustrated in (2a). However, I still believe this paper serves as an important contribution towards the proper analysis of the PPC, especially considering the oversimplifications and misconceptions that have been present in previous analyses, and which will be discussed in the sections below.

Some basic assumptions made in this work include the notion that there is a distinction between the morphology and the semantics of tense and aspect (no one-to-one correspondence) and that this varies from language to language (VON STECHOW, 2001, apud PANCHEVA, 2003). Moreover, I consider the syntactic structure of the Present Perfect as being parallel to the rest of the Perfect system. In the next section, I will briefly discuss some previous approaches to the U/E distinction for the PrP as well as some previous 
approaches aimed at accounting for the PPC's distinctive iterative property. Section 3 will present a review of the PTS approach to the Present Perfect as proposed by Iatridou et al. (2003) and Pancheva (2003), and how it will apply to the PPC. Section 4 involves a discussion of the role of adverbs and the possibility of covert adverbs in the Present Perfect. Section 5 concludes.

\section{Previous Approaches To The present Perfect}

\subsection{A Pragmatic Distinction}

When the $\mathrm{U} / \mathrm{E}$ distinction is conceived of as pragmatic in nature, the U-perfect is seen as a limiting case of the E-perfect (INOUE, 1979; MCCOARD, 1978; KLEIN, 1992, 1994). The U-perfect arises from vagueness with respect to the actual duration of the underlying stative predicate while other contextual elements determine which reading is understood, like adverbs or previously established discourse topics. So for an example like (1a), the eventuality being talked about is the living for 4 years, leaving open whether the living continues until speech time or not. The semantic contribution of the Perfect is simply "before R", while the location and duration of the eventuality remains unspecified. This means that there is a uniform semantic meaning for the Present Perfect, with the U/E differences derived from pragmatic elements.

\subsection{A Semantic Distinction}

Some arguments for semantic ambiguity include sequence of tense data as in (3).

(3) a. Since Christmas, John has claimed on several occasions that Mary was sick. (E)

b. Since Christmas, John has been claiming on several occasions that Mary was sick. (U)

c. John has always claimed that Mary was sick. (U)

E-perfects, as in (3a), allow for simultaneous and shifted readings such that Mary could have been sick at the time of John's claiming as well as before that time. On the other hand, U-perfects do no allow for simultaneous readings as shown in ( $3 b-c)$ which only have a prior sickness reading since the claiming eventuality continues up until and necessarily includes speech 
time. This way, U-perfects are semantically like a present tense (IATRIDOU et al., 2003).

Another argument for ambiguity comes from parallelism tests, or conjunction tests, in which both conjuncts must be of the same nature. That is, both conjuncts must be either U-perfects or E-perfects and not one of each, as (4) shows. If parallelism were not necessary, the ambiguity would be pragmatic in nature.

(4) John has been sick since 1990 and Mary has too. (IATRIDOU et al., 2003)

(*John is still sick, but Mary is better already.)t)

There are different ways to implement the semantic distinction. One way is for ambiguous adverbs to be built into the Present Perfect meaning. A sentence-final "for", as in ( $5 \mathrm{a})$, is ambiguous between U/E readings while a preposed-"for", in (5b), gives only a U-perfect (DOWTY, 1979). This view has been debated by some, although I will not go into the details of their particular analyses here (see RATHERT, 2003; ABUSCH; ROOTS, 1990). An immediate problem, however, would be how one could get the present perfect meaning when no adverbs are used, let alone other types of adverbs, like those of frequency or iterativity.

(5) a. John has been ill for three years. (but he's better now) b. For three years, John has been ill. (?but he's better now)

Another method for implementing the semantic distinction is through Aktionsart. For example, with U-perfects, speech time inclusion is not asserted but inferred, since stative predicates usually overflow their location time. This is illustrated by B's possible responses to A in (6), where either is appropriate and the first does not necessarily entail the second. Moreover, Gricean principles would prefer the present tense if the speaker has knowledge of continuation at speech time (MITTWOCH, 1988).

(6) A: I haven't seen John lately.

B: He's been ill / He is ill.

Aktionsart and adverbs contribute to the U/E-perfect meanings as well as to the U-perfect's assertion of speech time inclusion. Remaining ambiguities are ultimately interpreted from assessing other morphosyntactic elements of the sentence such as grammatical (viewpoint) aspect and (im)perfective morphology of the participle (for languages like Greek and 
Bulgarian, see IATRIDOU et al., 2003; PANCHEVA, 2003).

I will adopt the approach that treats the Present Perfect as introducing a PTS (Perfect Time Span) (IATRIDOU et al., 2003; PANCHEVA, 2003), which is based on the XN (eXtended Now) theory, but adapted for the benefit of accounting for the entire Perfect system and not just the Present Perfect. This approach will be reviewed in more detail in section 3 . The following subsection deals with previous attempts at analyzing the PPC.

\subsection{PoRtuguese}

\subsubsection{CAPTURING ITERATIVITY}

The main property of the PPC that distinguishes it from most other Present Perfects is its apparently obligatory iterative reading, as in (2a), where it could only refer to repeated visits to Disneyland and not one. This is further illustrated by its frequent translation into the Present Perfect Progressive in English. Giorgi and Pianesi (1997) propose a covert generic habitual operator to account for the obligatory iterative reading. The immediate problem is the fact that iterativity is not always obligatory, as show in (2b) with a stative predicate. Moreover, Giorgi and Pianesi are forced to stipulate not only a Present Perfect structure distinct from the rest of the Perfect system, but that there are two types of 'have', a main verb and an auxiliary. Schmitt's (2001) proposal suffers from the same drawback when she claims that the present tense morphology in Portuguese selects for states, explaining why it is only in the present that the Perfect is forced into an iterative reading. And since the Perfect outputs a non-homogenous predicate, coercion takes place to account for the mismatch, resulting in iteration. Again, the problem of durative readings with stative predicates are not accounted for.

\subsubsection{EXPRESSING IMPERFECTIVITY}

In the face of the possibility of iterative as well as durative readings, some theorists have looked for properties of imperfectivity lurking in the PPC meaning. Travaglia (1994) and Squartini and Bertinetto (2000), among others, describe the PPC as a structure expressing imperfectivity in the sense that the situation is iterative, unfinished and often compatible with the notion of habituality. Travaglia admits the possibility of a durative reading. However, those who have claimed that the PPC is a kind of imperfective have made no 
attempt to explain how this property comes into play or how it relates to the more traditional perfective-imperfective morphological distinctions. This imperfective characteristic of the PPC has led to claims that it expresses only the U-perfect reading (BRUGGER, 1978; SQUARTINI; BERTINETTO, 2000; PANCHEVA, 2003), which I will dispute in this paper.

\subsubsection{A Count-Mass AnALOGY?}

Ilari (2001) highlights the plural nature of iterative readings, suggesting they can be treated along the lines of the "principle of cumulative reference" such that:

(a) If $a$ is water and $b$ is water, then the sum of $a$ and $b$ is water.

(b) If the animals in this camp are horses and the animals in that camp are horses, then the animals in both camps are horses. (ILARI, 2001 p. 150)

Mass nouns are thus assimilated to plurals and, assuming the analogies between the temporal-nominal domains, predicates described with the PPC can be said to express a plurality of events in a similar manner. It is suggested earlier in Ilari's paper that one semantic rule should be responsible for the main PPC structure, and applying stative versus nonstative predicates would allow for the derivation of the durative versus iterative readings, respectively. So, roughly speaking, the mass-plural (eventive predicate) analogy would take care of the iterative reading while the mass-singular (stative predicate) analogy would take care of the durative reading. However, it is not clear how the durative-iterative ambiguity would be taken care of where the same predicate is concerned. Using Ilari's example,

(7) A biblioteca tem ficado fechada. The library has stayed closed. 'The library has stayed closed.'

where the predicate 'ficar' ('stay') is a stative, and could mean either a single, durative closing or intermittent closings with an understood set of time intervals being referred to, like 'on Sundays'. Thus, it would seem that more than just the aspectual class information is needed to derive the different readings from the single semantic rule. As hinted to in Ilari's text, the mass-count reference is not necessarily a characteristic limited to the lexical items as it is of the whole sentential context in which they occur 
(ILARI, 2001, p. 149). The idea that more syntactic elements need to be taken into account for a proper compositional analysis of the different readings in the Present Perfect will be exploited along the course of this study.

\section{The present Perfect Meaning And The U/E Distinction}

In the framework assumed here, the Perfect introduces the PTS (Perfect Time Span) interval, which is not equal to the eventuality that is introduced within it (IATRIDOU et al., 2003; PANCHEVA, 2003). For E-perfects, the eventuality is located in the PTS, while for U-perfects, the eventuality lasts throughout the PTS, including its endpoints. The left boundary (LB) of the PTS can be introduced by an adverb, like 'since 1990' and the right boundary (RB) is introduced by the tense of the auxiliary. In the case of the Present Perfect, then, RB includes speech time. The PTS holds for all Perfects (Past, Future and nonfinite), not just the Present Perfect (see PANCHEVA, 2003).

\subsection{GRAMMATICAL (VIEWPOINT) ASPECT}

Following Pancheva (2003), the Perfect is structurally more complex that the (im)perfective and is syntactically higher than viewpoint aspect. The Perfect is thusly an embedded tense. The different readings of the Present Perfect are composed of some elements shared by both and some that are specific to each. Consider the figure in (8) below. There is a uniform meaning for all types of perfects at AspP, where PTS is introduced ( $[\mid$ PERFECT $\mid]=$ ëpëi $\$ \mathrm{i}^{\prime}\left[\operatorname{PTS}\left(\mathrm{i}^{\prime}, \mathrm{i}\right) \& \mathrm{p}\left(\mathrm{i}^{\prime}\right)\right.$; PTS(i',i) iff $i$ is a final subinterval of $\left.i^{\prime}\right)$. There is a common syntax for all Perfects which is associated with a common meaning, the denotations of the heads.

(8) Syntactic components of the Perfect

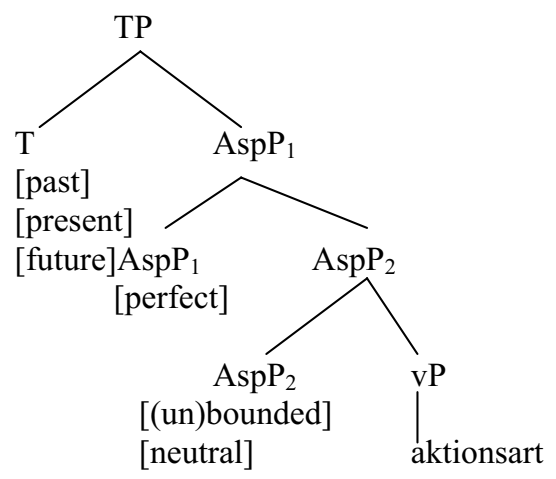


The semantic role of the Perfect is to introduce the PTS $\mathrm{S}_{i}$ and temporally relate it to $\mathrm{R}$ (eference time), its final subinterval. The viewpoints relate $\mathrm{E}$ (ventuality) to $\mathrm{R}$. This is where the readings differ and where crosslinguistic variation is most likely to occur. Some languages, like Greek and Bulgarian, express these viewpoints morphologically on the participle with (im)perfective markings (IATRIDOU et al., 2003).

With an [UNBOUNDED] viewpoint, the underlying eventuality is asserted to hold throughout the PTS interval, necessarily including its endpoints. With a [NEUTRAL] viewpoint, the underlying eventuality is asserted to begin within the PTS interval, making no claim about whether the event ends within the PTS interval. With a [BOUNDED] viewpoint, the underlying eventuality is asserted to begin and end within the PTS interval. Given the definitions of the $U$ and $E$ Perfects, only [UNBOUNDED] viewpoints are capable of giving rise to U-perfects, while [NEUTRAL] and [BOUNDED] viewpoints give rise to E-perfects. If we accept this characterization of the Perfect and the aspectual makeup of the Participle ( $\mathrm{AspP}_{1}$ and $\left.\mathrm{AspP}_{2}\right)$, it can be shown that Portuguese presents not only U-perfects, but E-perfects as well.

\subsection{Putting It Together}

In this section, I will apply the assumed framework to Present Perfect data from English. For [UNBOUNDED] viewpoints, a nonprogressive state plus an adverb is necessary for a U-perfect reading.

(9) [UNBOUNDED] + state (nonprogressive) + adverb $=$ U-perfect

'Since' alone is not sufficient for a U-perfect and can lead to ambiguity. A U-perfect under the circumstances in (10) is possible with the use of 'always' or 'ever since'.

(10) I've (always) been sick (ever since last week).

[UNBOUNDED] progressive nonstates can give a U-perfect reading with an adverb. However, eventualities described in Perfect Progressives do not necessarily include the right boundary, even with a perfect-level adverb. The subject does not have to be cooking at speech time (the right boundary) for the sentence in (11) to be true. This counters the claim in the framework put forth by Pancheva (2003) and Iatridou (2003) such that the eventuality necessarily includes the endpoints. 
(10) [UNBOUNDED] + nonstate (progressive) + adverb $=$ U-perfect

(11) I've been cooking at home (ever since I lost my job).

For neutral viewpoints, nonprogressive states can give rise to an E-perfect reading. Under these circumstances, no assertion is made about the inclusion of the right boundary. Examples like (13) are compatible with continuous readings that include speech time, but this is a matter of inference and not an assertion of the neutral E-perfect.

(12) [NEUTRAL] + state (nonprogressive) $=$ E-perfect

(13) I've been sick lately (but now I'm better)

E-perfects arise as well with [NEUTRAL] viewpoints and progressive nonstates. They are compatible with readings of repetition as in (15).

(14) $[$ NEUTRAL] + nonstate (progressive) $=$ E-perfect

(15) I've been cooking at home lately (but I want to eat out from now on)

Finally, [BOUNDED] viewpoints with any kind of nonprogressive eventuality will give rise to an E-perfect, as seen in (17-18).

(16) $[$ BOUNDED] + any (nonprogressive) $=$ E-perfect

(17) I've been sick before

(18) I've run/ built a house/ arrived late before

Here is a table summary of the data discussed above, taken from Pancheva (2003).

(19) English (PANCHEVA, 2003)

\begin{tabular}{|l|lc|l|}
\hline Perfect Type & $\begin{array}{l}\text { Viewpoint Aspect } \\
\text { Semantics }\end{array}$ & Morphology & Aktionsart \\
\hline Universal & {$[$ UNBOUNDED $]$} & $\begin{array}{c}\text { non-progressive } \\
\text { progressive }\end{array}$ & $\begin{array}{l}\text { State } \\
\text { Activity, telic }\end{array}$ \\
\hline Existential & {$[$ NEUTRAL] } & $\begin{array}{c}\text { non-progressive } \\
\text { progressive } \\
\text { non-progressive } \\
\text { progressive }\end{array}$ & $\begin{array}{l}\text { State } \\
\text { Activity, telic }\end{array}$ \\
& Any \\
\hline
\end{tabular}


Now, let us turn to Brazilian Portuguese and see how this data will work in the assumed framework. [UNBOUNDED] viewpoints combine with nonprogressive states and adverbs to give a U-perfect reading.

(20) [UNBOUNDED] + state (nonprogressive) + adverb = U-perfect

(21) Eu tenho estado doente (desde a semana passada).

I have been sick (since the last week)

'I have been sick (since last week)

Under these circumstances, there can be no ambiguity similar to the one in English where one could express that $\mathrm{s} /$ he has been sick once or even at least once in the interval of time determined by the adverb. U-perfects also arise with the combination of [UNBOUNDED] viewpoints and nonprogressive nonstates and adverbs.

(22) [UNBOUNDED] + nonstate (nonprogressive) + adverb $=$ U-perfect

Notice that for nonstates, the corresponding morphology is nonprogressive but still can produce a continuous, repetitive reading just as the English Perfect Progressive, which is the structure often used in translation of the PPC. Similarly to nonstative Perfect Progressives in English, right boundary inclusion is cancelable with something like 'mas não mais' ('but not anymore'), regardless of adverb. See examples (23-26). In the last example (26), the painting is understood as incomplete.

(23) Eu tenho corrido aqui (desde a semana passada)

I have run here (since the last week)

'I have been running here (since last week)'

(24) Eu tenho chegado tarde (desde a semana passada)

I have arrived late (since the last week)

'I have been arriving late (since last week)'

(25) Eu tenho percebido que está mais magro.

I have noticed that (you) are more thin

'I have been noticing that you're thinner'

(26) Eu tenho pintado um quadro (desde a semana passada)

I have painted a picture (since the last week)

'I have been painting a picture (since last week)' 
The PPC has a [NEUTRAL] aspect because right boundary inclusion is not obligatory, such that it can often be canceled. This is illustrated in (2830). This means that under [NEUTRAL] viewpoints and nonprogressive statives, an E-perfect is possible. 'Lately' is often used as a diagnostic for whether a PPC construction is acceptable and is vague about whether speech time is included in its assertion.

(27) [NEUTRAL] + state (nonprogressive) $=$ E-perfect

(28) Eu tenho estado doente ultimamente (mas já estou melhor) I have been sick lately (but already (I) am better) 'I have been sick lately (but I'm better already)'

(29) Eu tenho ficado no quarto ultimamente

I have stayed in-the room lately

'I have been staying in the room lately'

(30) Eu tenho sido feliz ultimamente

I have been happy lately

'I have been happy lately'

The same goes for [NEUTRAL] viewpoints and nonstatives. The main difference is the variation (in terms of acceptability) between complete or incomplete executions of the eventuality in question, as in (33-34).

(31) [NEUTRAL] + nonstate (nonprogressive) $=$ E-perfect

(32) Eu tenho corrido na praça ultimamente

I have run in-the park lately

'I have been running in the park lately'

(33) ?Eu tenho construído uma casa (a casa não está completa) I have built a house (the house not is complete) 'I have been building a house (the house is incomplete)'

(34) Eu tenho lido um livro (leituras completas ou incompletas) I have read a book (readings complete or incomplete) 'I have been reading a book (complete or incomplete readings)'

(35) Eu tenho chegado tarde ultimamente

I have arrived late lately

'I have been arriving late lately'

As expected, [BOUNDED] viewpoints are not possible with the PPC regardless of aktionsart. This is most salient with adverbs like 'before' or 'previously', as seen in the examples below. This is a symptom of the fact that the PPC cannot express any specific number of bounded events, whether 
they refer to one or three occurrences. That is, the number of eventualities described by the PPC must be left indefinite. The chart in (41) summarizes the data in BP.

(36) $[$ BOUNDED $]+$ no aktionsart $=Æ$

(37) *Eu tenho estado doente antes/ anteriormente

I have been sick before / previously

(38) *Eu tenho corrido aqui antes

I have run here before

(39) *Eu tenho construído uma casa antes

I have built a house before

(40) *Eu tenho achado os meus óculos aqui antes I have found the my glasses here before 'I have been finding my glasses here before'

(41) Brazilian Portuguese

\begin{tabular}{|l|lc|l|}
\hline Perfect Type & $\begin{array}{l}\text { Viewpoint Aspect } \\
\text { Semantics }\end{array}$ & Morphology & Aktionsart \\
\hline Universal & {$[$ UNBOUNDED $]$} & $\begin{array}{c}\text { non-progressive } \\
\text { progressive }\end{array}$ & $\begin{array}{l}\text { State } \\
\text { Activity, telic }\end{array}$ \\
\hline Existential & {$[$ NEUTRAL] } & $\begin{array}{c}\text { non-progressive } \\
\text { progressive }\end{array}$ & $\begin{array}{l}\text { State } \\
\text { Activity, telic }\end{array}$ \\
& {$[$ BOUNDED $]$} & $\begin{array}{c}\text { non-progressive } \\
\text { progressive }\end{array}$ & Any \\
\hline
\end{tabular}

Summing up, the PPC does not present a [BOUNDED] viewpoint and is restricted to [UNBOUNDED] and [NEUTRAL] viewpoints, not just [UNBOUNDED] as previously claimed. One important drawback of this framework is that it does not provide us with an explanation of WHY this is so. Why do some languages present some viewpoints and not others? Why are there restrictions? These questions were also left unanswered in Pancheva (2003). However, if we take these results at face value, there is still the issue of the U/E ambiguity at hand. Whether the PPC also presents the U/E ambiguity hinges on how we define adverbs and their role in conjunction with the Perfect structure, to be discussed below.

\section{A Closer Look At The Role Of Adverbs}

The main claims about the U-perfect in the PTS include the stipulation that it never occurs without an adverb. There is no independent reason 
provided for this claim. Given this definition for U-perfects, by elimination, covert adverbs (if there are any) can only occur with E-perfects. Another major claim is that the eventuality in a U-perfect must include its endpoints. The main claim about the E-perfect in the PTS is that it can occur without an adverb. However, if an adverb is not recoverable from the context, it occurs with a covert (at least) ONCE. There are two levels of adverbs: perfect-level and eventuality-level. Those adverbs that make the U-reading possible, but not necessary, include 'since' and 'for 5 days' and this is where the U/E ambiguity comes about. Adverbs that make the U-reading obligatory include 'at least since', 'ever since', 'always', 'for five days now'.

\subsection{Adverbs And The U/E Ambiguity}

\subsubsection{PERFECT-LEVEL ADVERBS}

With durative perfect-level adverbs, the eventuality must hold of every subinterval of the PTS, including right and left boundaries. With inclusive perfect-level adverbs, the eventuality is properly included in the PTS.

\section{SINCE / DESDE}

The argument of 'since' sets up the left boundary of the PTS. This adverb is ambiguous between a durational (U-perfect) and an inclusive (Eperfect) reading. 'Since' by itself is not enough to elicit a U-perfect reading so it could be said that this adverb is neither durational nor inclusive, but a default perfect-level adverb. This would mean that it only sets up a left boundary and all readings are permitted (von STECHOW apud IATRIDOU et al., 2003). If we were to accept this last suggestion, it would then conflict with the assumption that U-perfects only arise with adverbs and that right boundary inclusion is a main assertion of this kind of Perfect. The U/E ambiguity with 'since' ultimately means that the stative predicate either holds throughout the interval or occurs at least once within the interval. See (42).

(42) a. John has been in New York (once) since Monday b. O João tem estado em Nova Iorque (*uma vez) desde segunda-feira. 
'Desde' does NOT select for the Perfect in BP, so a U-perfect that necessarily includes speech time would be made using the simple present, as in 'Eu estou doente desde a semana passada'. For the PPC, while speech time inclusion can be canceled ([NEUTRAL]), a durative, $\mathrm{U}$-perfect reading is the most salient while a [BOUNDED] E-reading is infelicitous.

\section{FOR / POR}

These adverbs can be either perfect-level or eventuality-level; that is they do not require the Perfect. The $\mathrm{U}$ or E readings are a result of whether the adverb is understood as perfect-level or eventuality-level. How we know which one it is depends on context, modifiers, etc. This would be an argument against the claim that the basic U-perfect meaning must express obligatory inclusion of the endpoints of the PTS interval, if we're depending on other elements like context for interpretation. The U/E ambiguity with 'for' means that the stative predicate holds throughout whatever interval that is marked by 'for'. This interval is equivalent either to the PTS interval (perfect-level) or equivalent to the duration of the eventuality only (eventuality-level). This latter meaning is not possible in BP because, again, The [UNBOUNDED] Ureading is acceptable in both languages, but the [BOUNDED] E-reading (with 'before') is not possible in Portuguese. This is illustrated in (43).

(43) a. John has been sick for two weeks (before).

b. O João tem estado doente por duas semanas (*antes).

(44) a. The child has stayed in the "Punishment Corner" for two minutes.

(before)

b. A criança tem ficado no "Canto de Castigo" por dois minutos.

However, when the ambiguity is between an [UNBOUNDED] Ureading and a [NEUTRAL] E-reading, then it is possible in BP. Again, in (43a) a [BOUNDED] E-reading is possible as well for English, but not for Portuguese. Regarding the adverbs 'Since'/ 'Desde' and 'For' / 'Por', the PrP is ambiguous between an [UNBOUNDED] U-perfect reading and a [BOUNDED] E-perfect reading. The PrP is also ambiguous between an [UNBOUNDED] U-perfect reading and a [NEUTRAL] E-perfect reading. The Portuguese PPC is only ambiguous between an [UNBOUNDED] U-perfect reading and an [NEUTRAL] E-perfect reading. 


\subsubsection{COVERT Adverbs}

As I have already mentioned, assuming a strict definition for Uperfects, such that they always have an explicit adverb, means that if there is to be any covert adverb involved in the meaning of the Present Perfect, then it would only be with E-perfects. This is a convenient assumption, because if we don't assume this definition, we would have a problem with what covert adverb to choose and when. It could be argued that a Perfect interpretation is possible without adverbs and so there is no need for covert adverbs at all. In fact, U-readings are possible, but only as a matter of inference and not assertion, when a [NEUTRAL] viewpoint is involved. This way, a continuous reading that includes speech time is compatible with the eventuality described by the Present Perfect, but this is not part of the assertion (IATRIDOU et al., 2003; PANCHEVA, 2003). If we are to accept this argument in the long run, the nature of the inferences and assertions should be made more clear (i.e. presuppositions or implicatures? vs. entailments?). However, considering the pervasive use of adverbs with the Present Perfect and that an adverb is always recoverable from the context if not made explicit, it is plausible that covert adverbs have a place in the logical form of the Present Perfect meaning.

\section{(AT LEAST) ONCE}

'(At least) once' is the natural choice for the covert adverb of PrP E-perfects, given the existential logical operator's (\$) meaning of '(at least) once'. However, there are some problems to consider. See (45).

(45) Mark has read "Calvin and Hobbes" five times

A problem for Portuguese is that the PPC is infelicitous with not only '(at least) once', but with 'once', 'twice' and all other definite iterative adverbs (see (46)), unless it is embedded under a frequency adverb, like 'five times a week'.

(46) O Marcos tem lido "Calvin and Hobbes" *uma vez / * cinco vezes.

The Marcos has read "Calving and Hobbes" one time / five times.

'Marcos has read "Calvin and Hobbes" once / five times.' 
Although (45) and (46) both involve E-perfects, the discrepancy is due to the different viewpoints embedded under the Perfect. The covert adverb 'once' is only compatible with a [BOUNDED] E-perfect and not a [NEUTRAL] E-perfect, since only bounded eventualities can be quantified over. [NEUTRAL] E-perfects only assert that the eventuality began within the PTS interval and nothing about the right boundary. So, '(at least) once' as a covert adverb isn't compatible with English E-perfects with a [NEUTRAL] viewpoint either. This explains the variable adverb compatibility between languages. If we distinguish between frequency ('regularly', 'often', 'usually', 'three times a week') and iterative adverbs ('many times', 'once', 'three times') and furthermore between definite ('once', 'three times') and indefinite ('many times') iterative adverbs, we can see a distribution across the viewpoints. Since Portuguese does not have a [BOUNDED] viewpoint, it cannot receive definite iterative adverbs. Indefinite iterative adverbs are acceptable since they are compatible with [NEUTRAL] aspects in that no claim is made about the right boundary (-ies) of the eventuality(-ies). So, what's the covert adverb for [NEUTRAL] E-perfects?

\section{LATELY / ULTIMAMENTE}

'Lately' requires Perfect morphology (perfect-level) and does NOT form a U-perfect. 'Lately' requires the nonprogressive on statives and the progressive on nonstatives, and gives a habitual-like reading. Perfects with 'lately' are not U-perfects because they do not necessarily assert that the habit continues until speech time, although a continuous reading is compatible by inference. While 'lately' would be compatible with some [BOUNDED] Eperfects, it is not preferable to '(at least) once' since with these latter Perfects, there is no claim of recency or habituality, while the [NEUTRAL] E-perfect allows for this interpretation. As mentioned earlier, 'ultimamente' is often considered a diagnostic for whether certain eventualities are compatible with the PPC structure, another reason against the idea that Portuguese only has a U-perfect. These arguments favor the consideration of 'lately' / 'ultimamente' as the covert adverb of [NEUTRAL] E-perfects. See examples $27-29,31$ and 34.

Summing up, adverbs are part of the logical form of the Present Perfect meaning. Consider (47).

(47) a. [Adverb [ Perfect [ Viewpoint [ Adverb [ vP]]]]]

b. Since 1990, John has read "Magic Mirror" 5 times.

c. Desde 1990, o Marcos tem lido "Espelho Mágico" regularmente.

Since 1990, the Marcos has read "Mirror Magic" regularly. 
'Since 1990, Marcos has been reading “Magic Mirror” regularly.'

The first adverb position is perfect-level and the second adverb position is eventuality-level. One or both positions can be filled as shown in (47b-c). When no adverb is explicit, one must be recovered from other elements, like context. The adverb must be compatible with the values of the other elements of the Perfect meaning like viewpoint and Aktionsart, for example.

\section{CONCLUDING REMARKS}

Assuming a PTS approach to the Present Perfect, which is a version of the XN theory, it was shown that Portuguese not only presents $\mathrm{U}$ and $\mathrm{E}$ perfects (contrary to previous literature), it also presents the U/E ambiguity, although it is of a different nature than the traditional ambiguity found in English and other languages. The semantics of the Perfect as introducing the PTS interval is common to both English and Portuguese while the viewpoints are what distinguish between the readings available in each language. The viewpoints available in each language may affect adverb compatibility as shown by the PPC incompatibility with definite iterative adverbs. Due to the incompatibility of the covert 'once' with [NEUTRAL] E-perfects, a covert 'lately' was proposed, which works for both languages concerned.

In sum, the purpose of this paper was to look at a small portion of the meaning involved in composing the PPC. Though I was not out to provide an explicit account of the origins of iterativity in the PPC, an important step towards this must involve an analysis of the different readings and how they are composed within the PTS framework. The intention here was to shed some light on how the iterativity behaves with respect to lexical aspect, which is often not considered in analyses of the PPC, as well as the theoretical considerations adapted from Iatridou et al. (2003), while refraining, as the aforementioned authors also do, from providing an answer as to why certain languages have some perspectives and not others. It is important to understand how the iterativity arises in various contexts and the full extent of its restrictions before attempting a definitive analysis, such as proposing an ad hoc operator or an operation such as coercion, both of which clearly do not reflect all the possible readings that the PPC is capable of expressing. The latter claim was illustrated simply by taking lexical aspect into account. On the other hand, I agree with Schmitt (2001) that looking at the tense heads to see what selectional restrictions they impose on the kinds of predicates they take ${ }^{2}$ could lead to a productive analysis (MOLSING, 2007). Ultimately,

An approach also defended by Swart (1998) and Arosio (2003) for other languages 
I expect the final analysis to be a bit more involved, with the properties related to the simple present being a possible starting point for future work.

\title{
RESUMO
}

o presente trabalho trata do pretérito perfeito composto (PPC) e a possibilidade de leituras universais e existenciais. Vários estudos recentes sobre o "Present Perfect" ("Presente Perfeito") em línguas mais estudadas (e.g. Inglês, Alemão, Grego, Turco, etc.) descrevem as ambiguidades entre os dois tipos de leituras que frequentemente são definidos em termos da abordagem "Extended Now" ("Presente Estendido") (RATHERT, 2003; IATRIDOU et al., 2003; MCCOARD, 1978). A caracterização do Present Perfect nesta abordagem sofre de alguns problemas mesmo quando se trata de fenômenos nas línguas mais estudadas e também é sujeita a outros novos problemas na análise do PPC. Dado que análises anteriores têm tratado o Present Perfect somente em contextos com advérbios durativos, a natureza dos rótulos de 'universal' e 'existencial' ainda não foi testada com advérbios de frequência, por exemplo. Além disso, as poucas referências feitas em relação ao PPC têm declarado que este apresenta somente a leitura universal (SQUARTINI; BERTINETTO, 2000). É sabido, no entanto, que o PPC apresenta dois tipos de leituras, durativo (e.g. 'A Maria tem sido feliz') e iterativo (e.g. 'A Maria tem visitado os pais'). Estas limitações de abordagens do tipo Extended Now vão ser discutidas e modificações vão ser propostas para poder acomodar a leitura distinta de iteratividade em Português tanto quanto as leituras mais comuns de repetição encontradas em outras línguas.

Palavras-chave: Pretérito Perfeito Composto; Universal; Existencial.

\begin{abstract}
The present work deals with the Portuguese Present Perfect ('pretérito perfeito composto') and the possibility of Universal and Existential readings. Much of the literature on the Present Perfect of more studied languages (e.g. English, German, Greek, Turkish, etc.) describes the ambiguities that arise between these two types of readings which are often defined in terms of the Extended Now framework (RATHERT, 2003; IATRIDOU et al., 2003; MCCOARD, 1978). This framework's characterization of the Present Perfect runs into some problems
\end{abstract}


even when dealing with phenomena of the more studied languages and incurs some new problems when the Brazilian Portuguese Present Perfect is given a closer look. Given that previous analyses have only dealt with the Present Perfect in contexts with durative adverbs, the nature of the Universal and Existential labels have yet to be tested, with for example, frequency adverbs. Moreover, the few references made to the Portuguese Present Perfect have characterized it as having only a Universal reading (SQUARTINI; BERTINETTO, 2000). It is known, however, that the Portuguese Present Perfect has two types of readings, durative (e.g. 'A Maria tem sido feliz') and iterative (e.g. 'A Maria tem visitado os pais'). These limitations of Extended Now frameworks will be discussed and adjustments will be proposed in order to accommodate the unique iterative reading of the Portuguese Present Perfect as well as the more common readings of repetition in other languages.

Keywords: Present Perfect; Universal; Existential.

\section{REFERENCES}

ABUSCH, Dorit; ROOTS Mats. Temporal Adverbs and the English Perfect. Proceedings of NELS, 20, p. 5-19, 1990.

BRUGGER, Gerhard. Eventive time properties. In: DIMITRIADIS, A.; SIEGEL, L.; SURECLARK,C.; WILLIAMS, A. (Ed.). Proceedings of the annual penn linguistics colloquium, $21^{\text {st }}$, 1978, Pennsylvania. Pennsylvania Working Papers in Linguistics 4.2. Penn Linguistics Club, 1978, p. 51-63.

COMRIE, Bernard. Aspect. Cambridge: Cambridge University Press, 1976.

DOWTY, David. Word Meaning and Montague Semantics: the semantics of verbs and times in Generative Semantics and in Montague's PTQ. Dordrecht: D. Reidel Publishing Co., 1979.

GIORGI, Alessandra; PIANESI, Fabio. Tense and Aspect: From Semantics to Morphosyntax. New York: Oxford University Press, 1997.

IATRIDOU, Sabine; ANAGNOSTOPOULOU, Elena; IZVORSKI, Roumyana. Observations about the form and meaning of the Perfect. In: ALEXIADOU, A.; RATHERT, M.; VON STECHOW, A. (Eds.). Perfect Explorations. Berlin: Mouton de Gruyter, 2003. p. 153-205.

ILARI, Rodolfo. Notas para uma semântica do passado composto em português. Revista Letras, n. 55, p. 129-152, 2001.

INOUE, Kyoko. An analysis of the English present perfect. Linguistics, v. 17, p. 561-589, 1979.

KLEIN, Wolfgang. The Present Perfect Puzzle. Language, v. 68, n. 3, p. 525-552, 1992.

KLEIN, Wolfgang. Time in Language. London: Routledge, 1994.

MCCAWLEY, J. D. Tense and Time Reference in English. In: FILLMORE, C. J.; LANGENDOEN, D. T. (Eds.). Studies in Linguistic Semantics. New York: Holt, Rinehart and Winston, 1971. p. $96-113$. 
MCCOARD, Robert. The English Perfect: Tense Choice and Pragmatic Inferences. Amsterdam: North-Holland Press, 1978.

MITTWOCH, Anita. Aspects of English Aspect: On the Interaction of Perfect, Progressive, and Durational Phrases. Linguistics and Philosophy, v. 11, p. 203-254, 1988.

MOLSING, Karina Veronica. Reflexóes teóricas sobre o passado composto. Presentation handout, Nos domínios do verbo, UFPR, Curitiba, Paraná, August 2007.

PANCHEVA, Roumyana. The aspectual makeup of Perfect participles and the interpretations of the Perfect. In: ALEXIADOU, A.; RATHERT, M.; STECHOW, von A. (Eds). Perfect explorations. Berlin: Mouton de Gruyter, 2003. p. 277-308.

RATHERT, Monika. Universal-existential puzzles. In: ALEXIADOU, A.; RATHERT, M.; STECHOW, A. von (Eds.). Perfect explorations. Berlin: Mouton de Gruyter, 2003. p. 363381.

SCHMITT, Cristina. Cross-linguistic Variation and the Present Perfect: The Case of Portuguese. Natural Language and Linguistic Theory, v. 9, p. 403-453, 2001.

SQUARTINI, Mario; BERTINETTO, Pier.M. The simple and compound past in romance languages. In: DAHL, Ö. Tense and aspect in the languages of Europe. Berlin: New York: Mouton de Gruyter, 2000.

TRAVAGLIA, Luiz Carlos. O aspecto verbal no Português: a categoria e sua expressão. Uberlândia: Universidade Federal de Uberlândia, 1994.

Submetido em: 17/03/2007.

Aceito em: 01/09/2008. 